\title{
The Effect of Aqueous Fraction of Clinacanthusnutans (Burm.F.) Extract Microcapsules on Rat Blood Glucose Level
}

\author{
Ebta Narasukma Anggraeny ${ }^{*}$, Intan Martha Cahyani' ${ }^{1}$, Christiana Retnaningsih ${ }^{2}$, Victoria Kristina \\ Ananingsih $^{2}$, Masitoh Suryaning Prahasiwi ${ }^{1}$, Bekti Nugraheni ${ }^{1}$, Afri Diyah Nur Indah Sari ${ }^{1}$
}

1. College of Pharmaceutical Sciences Yayasan Pharmasi Semarang, College of Pharmaceutical Sciences Yayasan Pharmasi Semarang Jl. Letjend Sarwo Edie Wibowo Km 1 Plamongansari-Pucanggading Semarang-50193 Jawa Tengah-Indonesia

2. Soegijapranata Catholic University, Semarang, Jl. Pawiyatan Luhur Sel. IV No.1, Bendan Duwur, Kec. Gajahmungkur, Kota Semarang, Jawa Tengah 50234

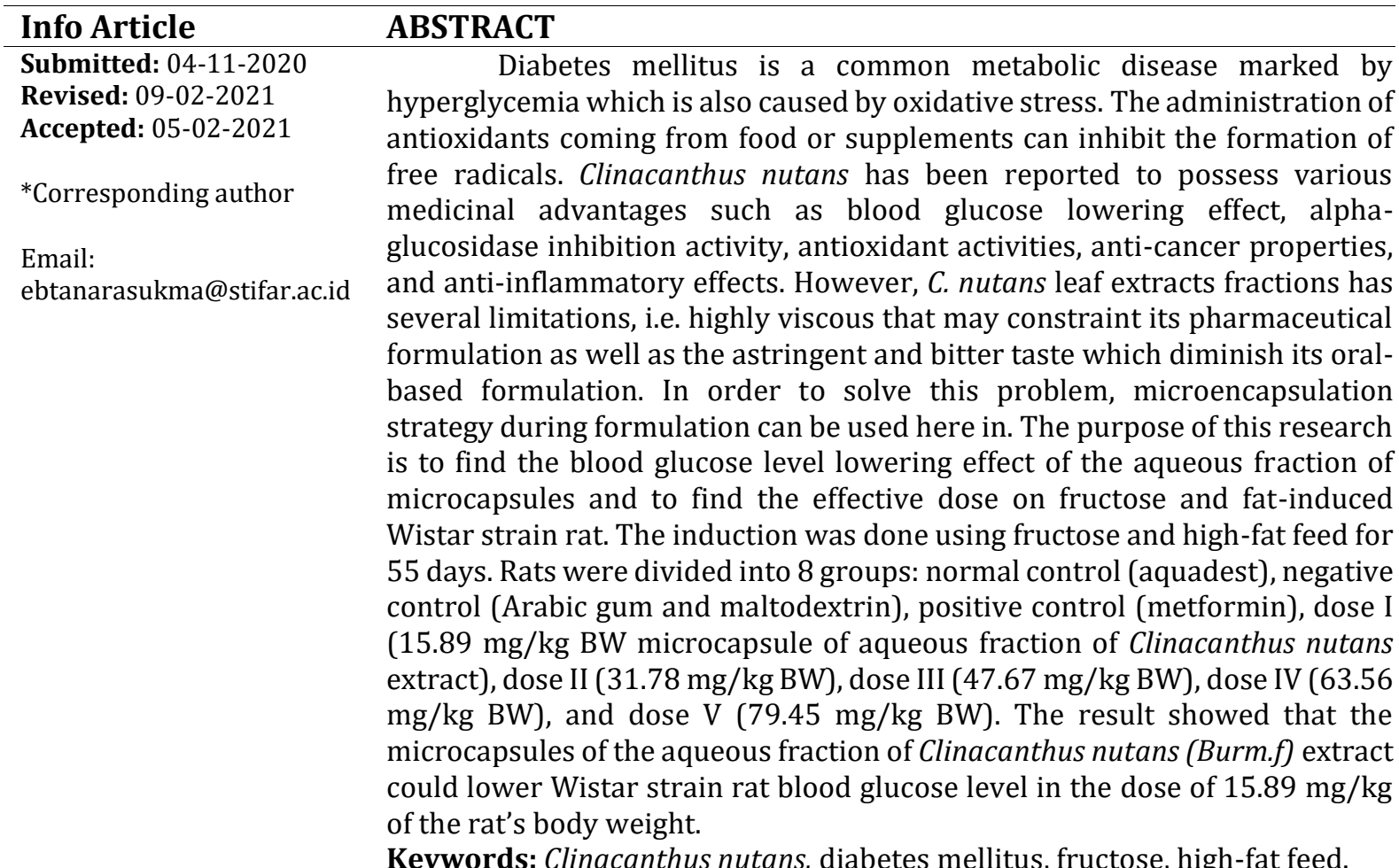

Keywords: Clinacanthus nutans, diabetes mellitus, fructose, high-fat feed.

\section{INTRODUCTION}

Indonesia is on the $6^{\text {th }}$ rank on the number of people with diabetes, with 10.3 millions of patients. Diabetes can be induced due to oxidative stress (Asmat et al., 2016). Oxidative stress occurs when there is imbalance between oxidative system and antioxidants in the cells and tissues (ROS) (PhamHuy et al., 2008). Antioxidants can be obtained either from food or supplements in order to inhibit the formation of free radicals (Chikezie et al., 2015). Clinacanthus nutans which is also called Sabah snake grass, is from family of Acanthaceae (Kunsorn et al., 2013). C. nutans is reported to have various medicinal properties, including blood glucose lowering effect, alpha-glucosidase inhibition, antioxidant activities, anti-cancer properties, and anti-inflammatory (Sakdarat et al., 2009). The aqueous extract of $C$. nutans leaves had antioxidant activity of $532.24 \mu \mathrm{g} / \mathrm{mL}$ (Nugraheni et al., 2017). The usage of $C$. nutans leaf extracts fractions has several problems, amongst them is its viscosity that gives difficulties in formulation and its astringent and bitter taste that makes it hard to be delivered orally. Herein, in order to solve these problems microencapsulation can be used (Munin and Edwards-Lévy, 2011).

Microencapsulation is a microscopic encapsulation process of drug particles with special coatings that improves physical and chemical properties of these particles (Cahyani et 
al., 2018). Optimization of maltodextrin and Arabic gum on the microencapsulation of aqueous fraction of $C$. nutans leaf extracts is carried out using simplex lattice design. The microcapsules can be produced using the ratio of 0.804 part maltodextrin and 0.194 part Arabic gum (0.804:0.194). The resulting microcapsules produced had $1.49 \%$ moisture level of $1.49 \%$, the solubility of $97.47 \%$, and the antioxidant activity was on of $842.499 \mathrm{ppm}$ (Cahyani et al., 2018). The aim of this study is to find the hypoglycemic effect of the microcapsules of aqueous fraction of $C$. nutans leaf extract.

\section{METHODS AND MATERIALS}

The sample used in this research is in the form of microcapsules form, which was made from the aqueous fraction of $C$. nutans leaves. The plant material of $C$. nutans leaves has been collected from Temu Kencono, Semarang. The test animals used were male Wistar strain rats aged 2-3 months, weighed 150-250g. Other materials used were fructose with the dose of $1.8 \mathrm{~g} / \mathrm{kg} \mathrm{BW}$ of mice body weight, HFF (combination of lard and duck egg yolk with the ratio of $(3: 1))$, metformin as a positive control with the dose of $0.126 \mathrm{~g} / \mathrm{kg}$, glibenclamide with the dose of $0.63 \mathrm{mg} / \mathrm{kg}$, and glucose with the dose of $6.75 \mathrm{~g} / \mathrm{kg}$.

\section{Sample preparation}

Microcapsules were made from 8 grams of aqueous fraction of $C$. nutans extract. To obtain the aqueous fraction, $200 \mathrm{~g}$ of $C$. nutans leaves powder were macerated with $2 \mathrm{~L}$ of ethanol $96 \%$ in 5 days. Then the aqueous extract was separated from ethanol solvent using a rotary vacuum evaporator at $40^{\circ} \mathrm{C}$. The extract was fractionated in stages with the liquid-liquid partition method using a separating funnel. The fractionation process was carried out by dissolving $10 \mathrm{~g}$ of concentrated ethanol extract with $100 \mathrm{~mL}$ of distilled water and stirring the mixture until all extracts were dissolved. Then, the mixture was put into a separating funnel with a capacity of $250 \mathrm{~mL}$ and fractionated using $100 \mathrm{~mL}$ of $\mathrm{n}$-hexane and then the mixture was shuffled. Two phases of mixture was produced and the aqueous layer was taken out. This process was repeated for 3 times. The aqueous residue obtained was then fractionated further with similar process using $100 \mathrm{~mL}$ ethyl acetate. The mixture then was shaken and left to form two layers, namely the ethyl acetate fraction and the aqueous fraction. The two layers then were separated while, the n-hexane fraction, ethyl acetate fraction, and the water fraction obtained were each evaporated on water bath at temperature of $80^{\circ} \mathrm{C}$.

Maltodextrin and Arabic gum were weighed according to the ratio, and then were mixed until they were homogenously dissolved. Then aqueous fraction of $C$. nutans extract was added, and then distilled water was added to the volume of $200 \mathrm{~mL}$. The mixture was put into the freezer for $24 \mathrm{~h}$, and then the frozen mixture was freeze-dried in the temperature of $-100^{\circ} \mathrm{C}$ and then the mixture was allowed to stand for $72 \mathrm{~h}$. The resulting microcapsules were sieved with no. 24 mesh sieve to form micro-sized microcapsules.

\section{Ethical clearance}

The proposed method was submitted to Komisi Etik Fakultas Kesehatan Masyarakat Universitas Diponegoro (FKM UNDIP). The certificate of ethical clearance was numbered No.023/ BC/FKM/2018.

\section{Test animal treatment}

Ten rats were not induced and 35 rats were induced with fructose and HFF for 55 days. Insulin resistance test was carried out on the $54^{\text {th }}$ day (the day before induction ended). After animal group test was done for insulin resistant, the 35 induced rats were further divided into seven groups, where each group consists of 5 rats. The groups received treatments according to the methods described below: Group I (negative control), Induced and administered with suspension of Arabic gum and maltodextrin orally from $56^{\text {th }}$ to $70^{\text {th }}$ day. Group II (positive control), Induced and administered with metformin orally with a dose of $0.126 \mathrm{~g} / \mathrm{kg}$ from $56^{\text {th }}$ to $70^{\text {th }}$ day. Group III, IV and V, VI, VII, Induced and administered with microcapsule of aqueous fraction of $C$. nutans extract orally with the dose of $15.89 ; 31.78 ; 47.67 ; 63.56$; and $79.45 \mathrm{mg} / \mathrm{kg}$ from $56^{\text {th }}$ to $70^{\text {th }}$ day.

\section{Evaluation of insulin resistance}

Ten animals from the sample groups were induced. The test animals induced were divided into these two following groups: Group $3=$ test animals induced without glibenclamide administration $(n=5)$; Group $4=$ test animals induced with glibenclamide $0.63 \mathrm{mg} / \mathrm{Kg} \mathrm{BW}$ administration $(n=5)$; The test animals without induction (normal feed) were also divided into two groups; Group $1=$ normal test animals without glibenclamide administration $(n=5)$; Group $2=$ normal test animals with glibenclamide 0.63 $\mathrm{mg} / \mathrm{kg} \mathrm{BW}$ ) administration $(\mathrm{n}=5)$. 
On the $54^{\text {th }}$ day, the test animals were fasted for 8-10 hours and later their blood was taken, and then their blood glucose level were measured. Insulin resistance test was carried out by administering glucose with the dose of $6.75 \mathrm{~g} / \mathrm{kg}$ orally and $30 \mathrm{~min}$ later the test animals were given glibenclamide. The test animals were given glibenclamide after $30 \mathrm{~min}$ treatment with glucose with the dose of $6.75 \mathrm{~g} / \mathrm{kg}$ orally. Two hours later, the blood of test animals were taken and the blood sugar glucose level was measured.

\section{Blood glucose measurement}

The blood of the test animals was taken through the ocular vein. The rat blood serum was obtained by centrifuging the rat blood at $3000 \mathrm{rpm}$ for $10 \mathrm{~min}$, then $1000 \mu \mathrm{L}$ glucose PAP reagent was added to $10 \mu \mathrm{L}$ of the serum and the resulting mixture was measured using Microlab 300. Blood glucose level was read in the unit of $\mathrm{mg} / \mathrm{dL}$.

\section{Analys data}

Data of percentage of blood glucose levels were analyzed using one-way ANOVA test and Post Hoc Test.

\section{RESULTS AND DISCUSSION}

This research was a follow up from previous research by Retnaningsih et al. (2009) in which aqueous fraction of $C$.nutans leaves had rat blood glucose lowering activity in the level of 15.89 $\mathrm{mg} / \mathrm{kg}$ BB. This study showed that aqueous fraction of ethanollic extracts of $C$. nutans leaves in the dose of $15.89 \mathrm{mg} / \mathrm{kg}$ was effective in reducing blood glucose levels in rats induced by fructose and highfat feed. The microcapsule dose was taken from the effective dose of aqueous fraction of $C$. nutans leaves. The aqueous fraction dose was then converted to microcapsule dose. The microcapsule dose obtained was $85.2072 \mathrm{~g}$, equal to $8 \mathrm{~g}$ of aqueous fraction. The aqueous fraction was selected for the microcapsule preparation because the aqueous fraction was found to have the highest antioxidant activity among the extracts and fractions.

In this study, the tested animals were orally induced to be hyperglycemic with fructose and HFF high-fat feed. The feeding of high-fat feed was expected to increase glucose level and free fatty acids in the cell plasma that will decrease the capability of the insulin receptor substrate in activating P13-kinase causing the decreases of the expression of GLUT4 and the activity of glucose transport, along with the blood glucose level increases (Shulman, 2000). In the liver, fructose is metabolized into free fatty acids that will be delivered in blood disrupting the metabolism and transport of glucose (Sun and Empie, 2012).

The result of insulin resistance evaluation showed that in the induced group, the group that received glibenclamide treatment still showed high blood glucose level. From this result, it can be concluded that the fructose and HFF can induce insulin resistance (Table I).

Table I. Insulin resistance test results with glibenclamide hypoglycemic effect test

\begin{tabular}{ccc}
\hline Group & $\begin{array}{c}\text { Blood Glucose Level (mg/dL) Day 54 } \\
\text { Without } \\
\text { Glibenclamide } \\
(\mathbf{n = 5})\end{array}$ & $\begin{array}{c}\text { With } \\
\text { Glibenclamide } \\
(\mathbf{n = 5})\end{array}$ \\
\hline Normal & $147.8 \pm 3.56$ & $123.60 \pm 9.10$ \\
Induced & $328.6 \pm 38.61$ & $240 \pm 31.83$ \\
\hline
\end{tabular}

This result showed that even with the insulin production stimulating effect of glibenclamide, the blood glucose level in the induced test animal was in the range of diabetic blood glucose level. Thus, it can be concluded that the fructose and HFF was capable of inducing insulin resistance. In the normal group, there was no any blood glucose level decrease observed because of the bodies' homeostasis mechanism in regulating blood glucose level. The hypoglycemic effects of glibenclamide in the normal group and in the induced group (Figure 1).

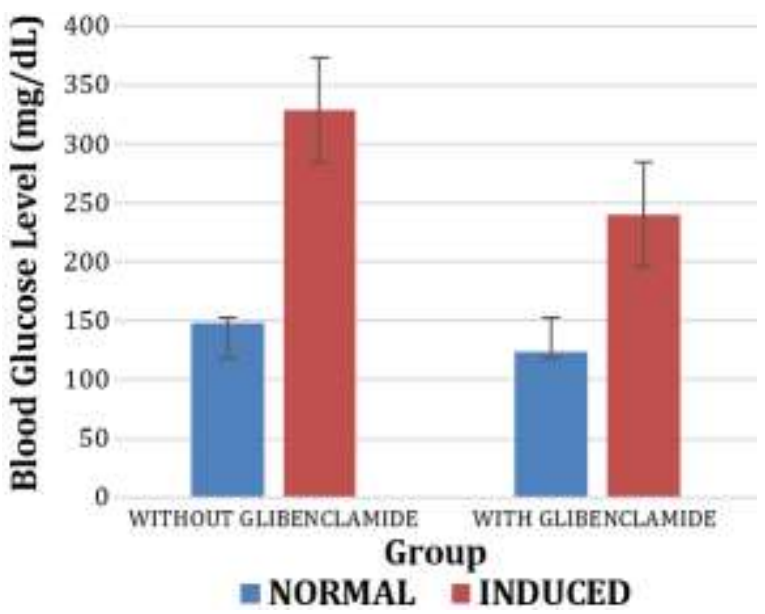

Figure 1. Hypoglycemic Effect of Glibenclamide in Normal and Induced Group 
Table II. Average blood glucose levels of all test animal groups and percentage of decrease in blood glucose levels

\begin{tabular}{|c|c|c|c|c|c|}
\hline \multirow{2}{*}{ Group } & \multicolumn{3}{|c|}{ Blood Glucose Level (mg/dL) } & \multirow{2}{*}{\multicolumn{2}{|c|}{$\begin{array}{l}\text { Decrease (\%) Differences with } \\
\text { Day 56-day } 70 \text { negative control }\end{array}$}} \\
\hline & Day 1 & Day 56 & Day 70 & & \\
\hline Normal & $119.2 \pm 26.01$ & $121.6 \pm 18.86$ & $120.6 \pm 18.11$ & $1.26^{\mathrm{b}}$ & -149.0 \\
\hline $\begin{array}{l}\text { Negative control: gum }+ \\
\text { maltodextrin }\end{array}$ & $133.2 \pm 56.18$ & $266.8 \pm 31.79$ & $269.6 \pm 32.41$ & $-1.05^{b}$ & $\mathbf{0}$ \\
\hline $\begin{array}{l}\text { Positive Control: } \\
\text { metformin }\end{array}$ & $115 \pm 14.75$ & $302.4 \pm 31.69$ & $163.72 \pm 11.88$ & $61.96^{\mathrm{a}}$ & 154.6 \\
\hline $\begin{array}{l}\text { Microcapsule dose I } \\
(15.89 \mathrm{mg} / \mathrm{Kg} \mathrm{BB})\end{array}$ & $96 \pm 16.45$ & $325.6 \pm 57.54$ & $228.35 \pm 38.11$ & $59.06^{\mathrm{a}}$ & 140.4 \\
\hline $\begin{array}{l}\text { Microcapsule dose II } \\
(31.78 \mathrm{mg} / \mathrm{Kg} \mathrm{BB})\end{array}$ & $107 \pm 16.81$ & $276.8 \pm 52.53$ & $228.76 \pm 54.38$ & $60.75^{\mathrm{a}}$ & 163.4 \\
\hline $\begin{array}{l}\text { Microcapsule dose III } \\
(47.67 \mathrm{mg} / \mathrm{kg} \mathrm{BB})\end{array}$ & $104 \pm 15.08$ & $281.8 \pm 58.56$ & $257.81 \pm 101.53$ & $61.79 a$ & 164.4 \\
\hline $\begin{array}{l}\text { Microcapsule dose IV } \\
(63.56 \mathrm{mg} / \mathrm{kg} \mathrm{BB})\end{array}$ & $117.6 \pm 8.85$ & $288.8 \pm 40.06$ & $199.67 \pm 31.88$ & $62.11^{\mathrm{a}}$ & 162.8 \\
\hline $\begin{array}{l}\text { Microcapsule dose V } \\
(79.45 \mathrm{mg} / \mathrm{kg} \mathrm{BB})\end{array}$ & $96.8 \pm 26.01$ & $266.8 \pm 28.18$ & $233.69 \pm 67.88$ & $63.57^{\mathrm{a}}$ & 174.4 \\
\hline
\end{tabular}

Blood glucose level before and after treatment

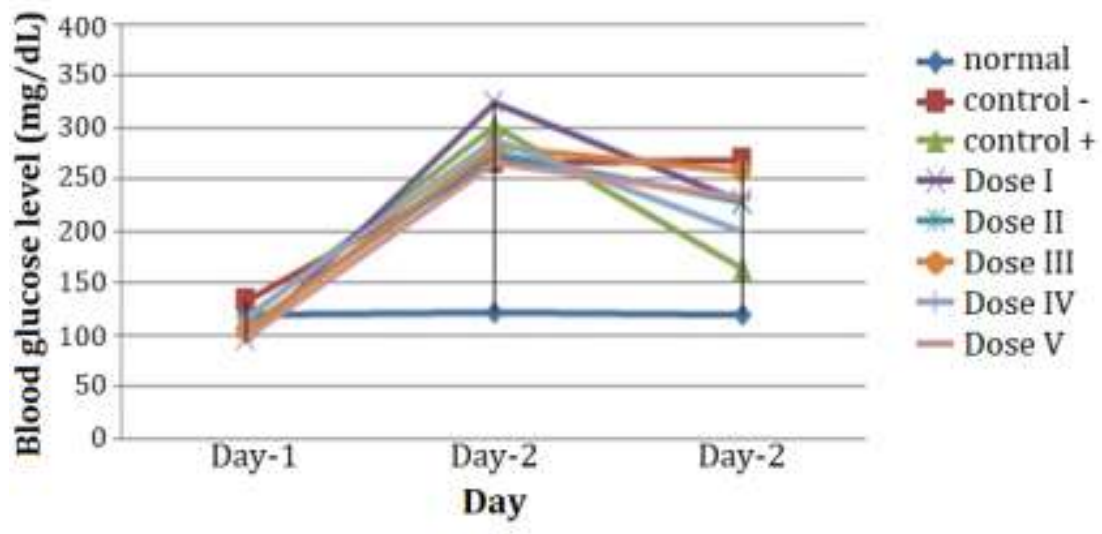

Figure 2. Average blood glucose level before and after treatment microcapsules of aqueous fraction C. nutans

The rats' blood glucose level was measured in the $56^{\text {th }}$ day, after the induction ended. From the result, paired-samples t-test showed $\mathrm{p}<0.05$, which means there was significant difference. This result showed the success of the induction process.

The test animals then were treated with the microcapsules of aqueous fraction $C$. nutans leaf extract for 14 days. In the $70^{\text {th }}$ day, the blood glucose level of all groups was measured to observe the blood glucose level decreasing effect of microcapsules of aqueous fraction of $C$. nutans leaf extract. The blood glucose level measurement result in the average number \pm SD (Table II and Figure 2).
The decrease percentages of blood glucose levels were examined using one-way ANOVA. The result obtained showed that $p$-value of 0.000 indicating that there is significant difference between the treatment groups. The further statistical test was the post-hoc test. The post-hoc test showed the percentage of blood glucose level decrease of the normal group which was showed by significant difference from the decrease of blood glucose level percentage in the negative group. From this result, it showed that maltodextrin and Arabic gum did not affect the rats' blood glucose level. The positive control group showed significant difference from the normal group, which means the 
research method is correct, since metformin is an antidiabetic agent which has already been proven in decreasing blood glucose level. The positive control group did not show significant difference with the treatment group with the doses 15.89 $\mathrm{mg} / \mathrm{kg}, 31.78 \mathrm{mg} / \mathrm{kg}, 47.67 \mathrm{mg} / \mathrm{kg}, 63.56 \mathrm{mg} / \mathrm{kg}$, and $79.45 \mathrm{mg} / \mathrm{kg} \mathrm{BW}$. This result means that the microcapsules of aqueous fractions of $C$. nutans leaf extract was proven to be capable of decreasing rats' blood glucose leveland has the comparable effectivity with metformin.

The use of metformin was based on the latest American Diabetes Association/ European Association for the Study of Diabetes (ADA/EASD) management guidelines for diabetes mellitus and the Association of Clinical Endocrinologists/American College of Endocrinology (AACE/ACE) recommendation. The AACE recommends metformin as the first line monotherapy. The mechanism of metformin is by inhibiting glucose production in the liver, decreasing the absorption of glucose in the digestive tract, and increasing insulin sensitivity (Abrori et al., 2017).

The previous study for the aqueous fraction showed that the aqueous fraction reduced $41.39 \%$ of blood glucose level. The microcapsules from the same aqueous fraction was able to reduce $59.06 \%$ of blood glucose level. Then, it can be concluded that microencapsulation improved the efficacy of aqueous fraction of $C$. nutans leaves.

The capability of the microcapsules in decreasing blood glucose level is related to the flavonoid content in $C$. nutans leaves. The aqueous fraction of $C$. nutans leaves contained flavonoid from the groups. The flavonoid compound found in C. nutans was $5,6,7,4^{\prime}, 5^{\prime}$ pentahydroxy flavone (Anggraeny et al., 2017).

The flavonoids contained in $C$. nutans have antioxidant and antidiabetic activities. The mechanism of flavonoids as antioxidants is based on the capability to suppress the apoptosis of $\beta$ Langerhans cells without altering the proliferations of those cells (Ruhe and McDonald, 2001). The $C$. nutans flavonoids mechanism as antidiabetic is by acting as glucosidase inhibitor. The $\alpha$-glucosidase inhibitors delay absorption of carbohydrates obtained from food, which can reduce blood glucose levels after eating (Ross et al., 2004).

\section{CONCLUSION}

The treatment of microcapsules of aqueous fraction of $C$. nutans leaf extract to male Wistar strain rats was proven to decrease blood glucose level significantly. The effective dose of microcapsules of aqueous fraction of $C$. nutans leaf extract was found to be $15.89 \mathrm{mg} / \mathrm{kg} \mathrm{BW}$ because it was able to give comparable effect to metformin.

\section{ACKNOWLEDGEMENTS}

Our thanks go to the Directorate of Research and Community Service of the Directorate General of Higher Education of the Ministry of Education and Culture who have funded the 2018 lecturer research with contract number of 057/K6/KM/SP2H/PENELITIAN/2018 and number 01/LPPM/PP/PENELITIAN/V/2018.

\section{REFERENCES}

Abrori, C., Tiya, L., and Rosalina, D. (2017). Slow Release Metformin Effect in Weight Loss and Total Calorie Intake in Obese Volunteers. Journal of Agromedicine and Medical Sciences, 3(1), 50-55. https://doi.org/10.19184/ams.v3i1.4098

Anggraeny, E. N., Cahyani, I. M., Nugraheni, B., Retnaningsih, C., and Ananingsih, K. V. (2017). Karakterisasi Senyawa Flavonoid Hasil Isolat Dari Fraksi Air Daun Dandang Gendis (Clinacanthus Nutans [Burm.F.] Lindau) Dan Aktivitas Antioksidannya. Seminar Nasional Kimia Dan Pendidikan Kimia V, 5, 101-104. https://artikel.snkpk.site/index.php/prosid ing/article/view/2/2

Asmat, U., Abad, K., and Ismail, K. (2016). Diabetes mellitus and oxidative stress-A concise review. Saudi Pharmaceutical Journal, 24(5), 547-553.

https://doi.org/10.1016/j.jsps.2015.03.013

Cahyani, I. M., Anggraeny, E. N., Nugraheni, B., Retnaningsih, C., and Kristina Ananingsih, V. (2018). The optimization of maltodextrin and arabic gum in the microencapsulation of aqueous fraction of Clinacanthus nutans using simplex lattice design. International Journal of Drug Delivery Technology, 8(2), 110-115.

https://doi.org/https://doi.org/10.25258/i jddt.v8i2.13877

Chikezie, P. C., Ojiako, O. A., and Ogbuji, A. C. (2015). Oxidative stress in diabetes mellitus. International Journal of Biological Chemistry, 1(3), 71-79. https://doi.org/10.3923/ijbc.2015.92.109

Kunsorn, P., Ruangrungsi, N., Lipipun, V., Khanboon, A., and Rungsihirunrat, K. (2013). The identities and anti-herpes simplex virus 
activity of Clinacanthus nutans and Clinacanthus siamensis. Asian Pacific Journal of Tropical Biomedicine, 3(4), 284-290. https://doi.org/10.1016/S22211691(13)60064-7

Munin, A., and Edwards-Lévy, F. (2011). Encapsulation of natural polyphenolic compounds; a review. Pharmaceutics, 3(4), 793-829.

https://doi.org/10.3390/pharmaceutics30 40793

Nugraheni, B., Anggraeny, E., Cahyani, I., Retnaningsih, C., and VK, A. (2017). Antioxidant Activity Test and Determination of Ec 50 Extract and Fraction of Dandang Gendis Leaves ( Clinacanthus Nutans ) By DPPH Method (1,1-Diphenyl-2Picrylhydrazyl) in Vitro Bekti Nugraheni. Proceeding of The 2nd UMP-PIC and 8th ISCC, October 2017, 98-103. https://digilib.ump.ac.id/gdl.php?mod=bro wseandop=readandid=jhptump-ump-gdlbektinugra-1991

Pham-Huy, L. A., He, H., and Pham-Huy, C. (2008). Free radicals, antioxidants in disease and health. In International Journal of Biomedical Science (pp. 89-96). https://www.ncbi.nlm.nih.gov/pubmed/23 675073

Retnaningsih, C., Ananingsih, V. K., Meiliana, Anggraeny, E. N., Cahyani, I. M., Nugraheni, B., and Efendi, R. (2019). The effect of clinacanthus nutans (Burm.f.) lindau water fraction addition on hypoglycemia,
International Conference on Food Science and Technology, 2018,. IOP Conference Series: Earth and Environmental Science, 292(1). https://doi.org/10.1088/17551315/292/1/012032

Ross, S. A., Gulve, E. A., and Wang, M. (2004). Chemistry and Biochemistry of Type 2 Diabetes. Chemical Reviews, 104(3), 12551282. https://doi.org/10.1021/cr0204653

Ruhe, R. C., and McDonald, R. B. (2001). Use of Antioxidant Nutrients in the Prevention and Treatment of Type 2 Diabetes. Journal of the American College of Nutrition, 20(5), 163S369S.

https://doi.org/10.1080/07315724.2001.1 0719169

Sakdarat, S., Shuyprom, A., Pientong, C., Ekalaksananan, T., and Thongchai, S. (2009). Bioactive constituents from the leaves of Clinacanthus nutans Lindau. Bioorganic and Medicinal Chemistry, 17, 1857-1860. https://doi.org/10.1016/j.bmc.2009.01.05 9

Shulman, G. I. (2000). Cellular mechanisms of insulin resistance. In Journal of Clinical Investigation (pp. 171-176). https://doi.org/10.1172/JCI10583

Sun, S. Z., and Empie, M. W. (2012). Fructose metabolism in humans - What isotopic tracer studies tell us. Nutrition and Metabolism, 9, 1-15. https://doi.org/10.1186/1743-7075-9-89 